\title{
Trainings and their Role in the Increase of Teachers' Civic Background and the Quality of Teaching, for an Active Participation in School and Community
}

\author{
PhD. Lindita Lutaj (Process) \\ "Aleksandër Moisiu" University, Durrës, Faculty of Education, Department of Pedagogy, Albania \\ Email: I.lutaj@yahoo.com
}

\section{Doi:10.5901/jesr.2016.v6n1p33}

\section{Abstract}

Our aspiration intends to enable all the children to develop their capacities as successful pupils, confident individuals, responsible citizens and effective contributors for the society. The trainings are designed to improve the quality, the efficiency of the education system, the facility to access this system as well as its prevalence all over the country. The experience of the last ten years focuses not only on the achievements but even on some flaws in the field of the civic education of the pupils, as well as on the necessity to make some changes and improvements in this field. The main goal of this study is to highlight the way how the teachers' trainings influence on the increase of their civic background and on the improvement of the quality of teaching, in order to find out their impact on the increase of the students' active participation in school and community. Also, it intends to highlight the relation between the training for the teachers' civic background and the training for the quality of teaching on one hand and the training for the pupils' civic participation in school and community on the other. This study is quasi-experimental and was carried out among $(N=60)$ teachers who teach the subject of Civic Education from the 6th-9th grade of the undergraduate education in the district of Durres.From the total number, 30 teachers were part of the experimental group and 30 others were part of the control group. Also, the pupils of these teachers, of the 6th-9th grade, $(N=1402)$ were involved in the study. The intervention X1 was carried out with three training packages regarding the teachers' civic background, as well as the intervention X2 with three training packages regarding the teaching quality. The statistical package of the social sciences was used for the analysis of the data (SPSS, 20). The findings proved that the teachers' training for civic education and the teaching quality increases their civic background level, the teaching quality and their civic participation. Regarding the report about the students, it was found that the teachers' training for the civic background and the teaching quality increases the perception about the teachers' civic background and the teaching quality, but it does not encourages the civic participation of the students. This is due to the fact that the teaching of the values and of the civic manners is complicated; it is a process which is conditioned by several factors, therefore rapid effects should not be expected. More work should be done in the long-term aspect continuously and persistently, in order to transmit the feedback and to establish the goals for improvements in the future. The high quality of the professional development is a central component for the education of the pupils and their active participation.

Keywords: Training, civic background, teaching quality, active participation, school, community.

\section{Summary}

The scope of this study is to find out which approach influences more on students' education to become active citizens, the interference via trainings to increase the quality of teachers' civic formation, or the interference via trainings to increase the teaching quality. That is why, teachers should possess the necessary competences while preparing the students for active civility in the school as well as in the community. The social and civic competences are considerably present, therefore, in the European cooperation in the field of education, they are part of the eight main competences identified by the European Council and Parliament in 2006, as crucial competences for the citizens, who live in the society of knowledge (Vassiliou, A., L'educazione alla cittadinanza in Europa, 2006, fq.3). "One of the main objectives of the Strategic Framework for European collaboration in the field of education and training until the year 2020 (Conclusioni del Consiglio del 12 maggio 2009) is the promotion of cohesion, social capital and active civility via education" (Vassiliou, A., L'educazione alla cittadinanza in Europa, 2009, pg. 3). In this context, the fulfilment of the teacher's needs gets more importance, in order to prepare active citizens of the future, who will be capable to face life. The member countries should provide the teachers and the entire academic staff, the youth leaders and the trainers with the necessary training as well as with the initial and continuous development in the field of education for democratic civility and for human rights. They should be offered the alternative to acquire full knowledge about the objectives and the principles of the subject, the adequate teaching and acquisition methodologies, as well as the necessary skills for this education field 
(Recommendation CM/Rec, 2010, pg.7).

In the curricular framework of Secondary Education in the Republic of Albania, the civic competence is among the key competences for acquisition during all the life. The competence, which is gained via the actions of the people in specific situations, and the frameworks which help to assess and develop it are the basis of a new paradigm, which connects the theories of the action with the situations and the development of the competences by the people. This new paradigm is being built at the moment. Under these circumstances, a curricular methodology is necessary. Its descriptions will assist the academic program to involve during a class the essential components for the development of the competences by the students (Karameta, P., Education of the Other Generation (Edukimi i Gjeneratës Tjetër), 2014, fq. 149).

"Based on these general goals, civics aims to prepare the future citizens to be capable of exercising their civic responsibilities and to cope successfully with the future challenges, participating actively in the social life" (Kaltsounis, T., 1998). It is easy to identify the issues, but it is much more difficult to find the courage to change this reality. Therefore, the question is: Which are the policies that may cause this change?

In order to be able to participate, the citizens have to gain the appropriate knowledge, values and skills. These preconditions for active civility are the ideal outcomes - or the output - of civic education. That is why we have identified them as the indicators of civic education output. In order to encourage the acquisition of these preconditions, civic education responsibility has to do with the transmission of knowledge, values and kills. "The role of the university in training and certifying the teachers as well as in providing the decent teaching quality is of a high importance" (Gora, C., Gore, V., Skolstvo, Z., 2007, fq. 32), because the universities should know their responsibilities for the teachers they prepare.

Article 12.2 of the "Law on the Secondary Education System" reads: "The community of the high schools, composed of the students, the teachers the rest of the staff, the parents and other social partners, tends to enhance students' academic and educative level and their optimal integration in the life, emancipation and development of the country" (Law on the Secondary Education System, Tirana, 1995, pg. 7). Above all, the important requirement is the preparation of the new generation as active citizens for the roles and the responsibilities they have to get in life. "The government has to provide trainings on civic education and on the involvement in a modern society. Of course, it is part of the society interest in general to educate the education up to some point. The school system is an efficient approach to fulfil the social needs" (Guomundur Heioar Frimannsson, 2000, pg.16).

Albanian transition period is characterized by the obvious lack of systematic and intensive investments on the teachers' training. During the last years, their training at work has been carried out in an uncoordinated way. Different non-governmental local or foreign agencies have been involved in the teachers' training. However, the lack of a complete and coherent approach has decreased the efficiency of these trainings. (National Strategy of Education, 2004-2015, pg.14). The absence of the monitoring and of the assessment of the training organisations reduces the efficiency of the trainings, which generally do not achieve the appropriate qualitative level.

Very serious steps have been made recently in this prospective, pursuant to the teachers' professional development strategy theoretically approved by MEA. The qualification examinations, the teachers' portfolios, the trainings for qualification, the seminars for the ministerial guidelines, the drafting of the standards for the teachers, for the directors, for the trainers, etc. are part of a significant progress. "The education institution plans the teachers' professional development according to their needs and in accordance with the central domestic education policies" (Law No. 69/2012, article 58, pg. 19). "Furthermore, it is important not to conceive the training in just one or a few séances. It continues with independent duties for the participants, which later on should be referred by them" (The Training and Qualification Centre for Education, Tirana, 2006, pg.6). "The current studies on the civic education programmes do not contain data about the active civility input indicators because they contain little information about what is happening with regard to civic education at school" (Weerd, M., Gemmeke,M., Rigter,J., Rij,C., 2005, pg. 64).

\section{Materials and Methodology}

This study is quasi-experimental and was carried out with teachers who teach civics from the sixth grade to the ninth grade of the secondary education in the district of Durres, in order to notice the influence of the trainings on the enhancement of the students' active participation level after the teachers were trained on their civic background and the improvement of the quality of teaching. The study is designed to find out if the teachers' training for their civic background, the teachers' training for the teaching quality, or the teachers' training for their civic background and the teaching quality encourages the students to participate in more advanced civic engagements rather than not having them 
at all.

A structured questionnaire was used in this study with 40 statements for the teachers and 30 statements for the students. The teachers' questionnaire was composed of four parts. 13 statements were included in the first part and 11 ones were included in the second part. They were measured with a scale of the type Likert with five divisions: I fully agree (5); I agree (4); I am uncertain (3); I disagree (2) and I do not agree at all (1). The scales are mainly used to measure the prospective and the opinions. In the third part, in order to measure the participation index, that means the civic behaviour, some questions with a scenario were used. They were 10 in total; because the behaviours are measured better via a scenario rather than the scales. Six questions were included in the fourth part. They focused on the demographic characteristics of the participants in the study, such as: the gender, the age, the education, the experience in education, the teaching experience in the subject of civics, the branch the respective teachers were graduated in. The same questionnaires were used for both the teachers and the students, taking into consideration the simplicity for the student's questionnaire, in a way that the questions were appropriate for their level. Seven statements were included in the first part of the questionnaire, eleven ones were used in the second part and 10 scenarios were used in the third part. The forth part of the questionnaire includes three questions regarding their gender and the grade the students were attending at the moment they would fill in the questionnaire.

The final sample were teachers $(\mathrm{N}=60)$ and students $(\mathrm{N}=1402)$ in 21 different schools in the district of Durres. Its determination was based on the Sample Size Table, From the Research Advisors, 2006, Confidence 95\%, Margin of Error 2.5\% (http://www.research-advisors.com/tools/SampleSize.htm). This sample of 60 teachers out of 98 teachers, who teach civics in the district of Durres, includes $61.2 \%$ of the teachers of civics in this district and at national level it includes $0.45 \%$ out of 13.438 teachers who teach civics. Initially, the experiment group was composed of 30 teachers: 10 teachers were part of the first group $\mathrm{N}_{1}$. They would undergo the intervention $X_{1} X_{2}$, with 6 training packets in total, where the $X_{1}$ intervention included 3 training packets for the civic background and the $X_{2}$ intervention included three packets for the teaching quality; 10 teachers of the $\mathrm{N}_{2}$ group would undergo the $X_{1}$ intervention with 3 training packets for the civic background and 10 teachers of the $\mathrm{N}_{3}$ group would undergo the $\mathrm{X}_{2}$ intervention with three training packets for the teaching quality. Initially, the first measure was carried out for all the groups. Then, the intervention with trainings was carried out. It lasted for about six weeks and a month later the second measure was carried out.

The three training packets for of the $X_{1}$ intervention for the civic background were: The civility values the teachers should possess and their transmission to the students, opened teaching; the variety of the actors' roles and the participation level of the students, the measures of civility and their role in the increase of the civic participation level. Meanwhile, the three packets about the teaching quality, which belong to the $X_{2}$ intervention were: the contemporary methods and their application efficiency in the participation of the students, the assessment as a process which improves teaching and motivates the students to go ahead, being knowledgeable and professional about the subject and the role of the teacher in a qualitative class.

After the selection of the experimental group, which was composed of 30 teachers, 30 other teachers were selected in the same random way to be part of the control group. No interventions with training packets were carried out in this group with regard to the civic background and the teaching quality. This training scheme is interpreted via this diagram:

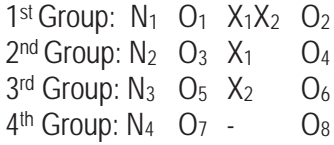

The structure has been designed intentionally to carry out the measurements $\mathrm{O}_{1}, \mathrm{O}_{3}, \mathrm{O}_{5}$ of the students' participation in the civic activities of an experimental group and then it is followed by the measurements $\mathrm{O}_{2}, \mathrm{O}_{4}, \mathrm{O}_{6}$. Parallel to these first measurements, the $\mathrm{O}_{7}$ and the $\mathrm{O}_{8}$ ones were carried out in the group of control $\mathrm{N}_{4}$. The measurements in the control group were carried out without implementing the interferences that were used in the e experiment group.

\section{Results and Discussion}

The statistical packet of social sciences was exploited during the analysis of the data (SPSS, 20). The average reported by the teachers who had already been provided with Post-test trainings $(A=50.46)$ is bigger than their Pre-test average $(A=50.22)$, meanwhile in the control group, the post-test reported average $(A=47.51)$ is smaller than the average reported by the pre-test students $(A=48.00)$. Also, the post-test average $(A=50.46)$ of the civic background reported by the 
teachers, who have been trained, is bigger than the average of the teachers who have not been provided with a training; their respective post-test average was $(A=47.51)$. As this result is important statistically $(1399)=14.11, p<.001$ (Table 1 ), we can say that the teachers' training influences on their civic background.

Table 1: The differences of the pre-test and post-test groups of the experiment and of the control for the civic background

\begin{tabular}{|c|c|c|c|c|c|c|c|c|}
\hline \multirow[b]{2}{*}{ Civic background } & \multirow[b]{2}{*}{$\mathrm{N}$} & \multicolumn{2}{|c|}{ Pretest } & \multicolumn{2}{|c|}{ Posttest } & \multirow[b]{2}{*}{$D f$} & \multirow[b]{2}{*}{$\mathrm{t}$} & \multirow[b]{2}{*}{$p$} \\
\hline & & $M$ & DS & $\mathrm{M}$ & DS & & & \\
\hline Experiment group & 705 & 50.22 & 4.77 & 50.46 & 4.21 & 704 & 317.842 & .000 \\
\hline Control Group & 696 & 48.00 & 4.93 & 47.51 & 3.55 & 695 & 353.034 & .000 \\
\hline
\end{tabular}

Regarding the teachers' civic background perceived by the students, the highest scores were reported in the training group with two packets $(A=35.83)$. Based on these findings, it is also noticed that in the three groups of the trained teachers, their students reported a higher average after the training compared to the one before the training (Graph 1).

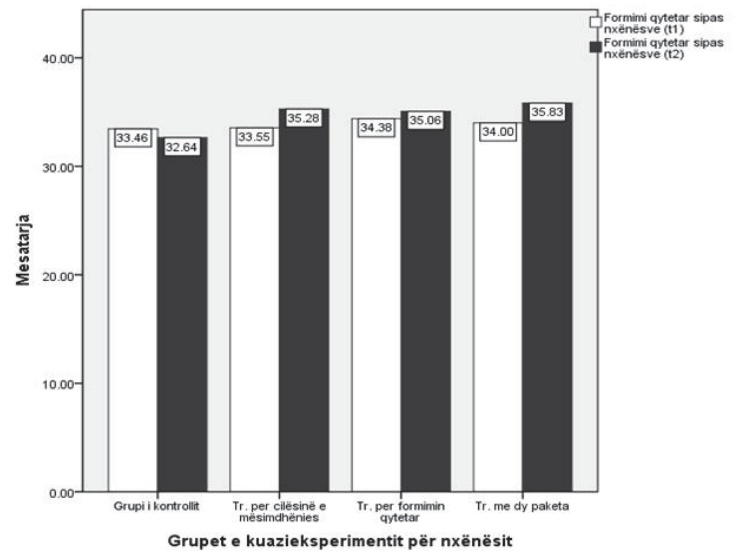

Graph 1: Comparison of the civic background before and after the training for the four groups of the students

It was noticed that the training with two packets ( $r=0.39$, moderated) had the strongest influence on the teachers' change regarding the civic background reflected on the students. We emphasize the fact that the teachers' civic background and the perception of the teachers' civic background by the students had the strongest statistical relation with the civic participation of the students $r=40(p<0.01)$.

Based on table 2, we notice that the post-test average of the teaching quality $(A=41.39)$ in the group of the trained teachers is higher than the pre-test average $(A=40.85)$. This difference is important statistically $t(704)=-4.374, p<$ .001 . The post-test average $(A=37.98)$ of the teaching quality, in the group of the teachers who had not been trained, is lower than the pre-test average $(A=38.70)$. This difference is important statistically $t(696)=7.697, p<.001$. Based on these findings, we can say that the training has influenced on the increase of the teaching quality.

Table 2: Differences of the pre-test and post-test experiment and control groups regarding the teaching quality.

\begin{tabular}{lcccccccc}
\hline & \multicolumn{9}{c}{ Pre-test } & \multicolumn{1}{c}{ Post-test } & & \\
\cline { 2 - 6 } Teaching quality & $\mathrm{N}$ & $\mathrm{A}$ & $\mathrm{DS}$ & $\mathrm{A}$ & $\mathrm{DS}$ & $d f$ & $\mathrm{t}$ & $p$ \\
Experiment group & 705 & 40.85 & 3.7 & 41.39 & 3.4 & 704 & -4.374 & .000 \\
Control group & 696 & 38.70 & 3.4 & 37.98 & 3.2 & 695 & 7.697 & .000 \\
\hline
\end{tabular}

It is also noticed that the students reported a higher average after the training than before the training regarding the three trained groups of teachers (Graph 2). 
Graph 2: Comparison of the teaching quality averages before and after the training for the teachers' control and training group

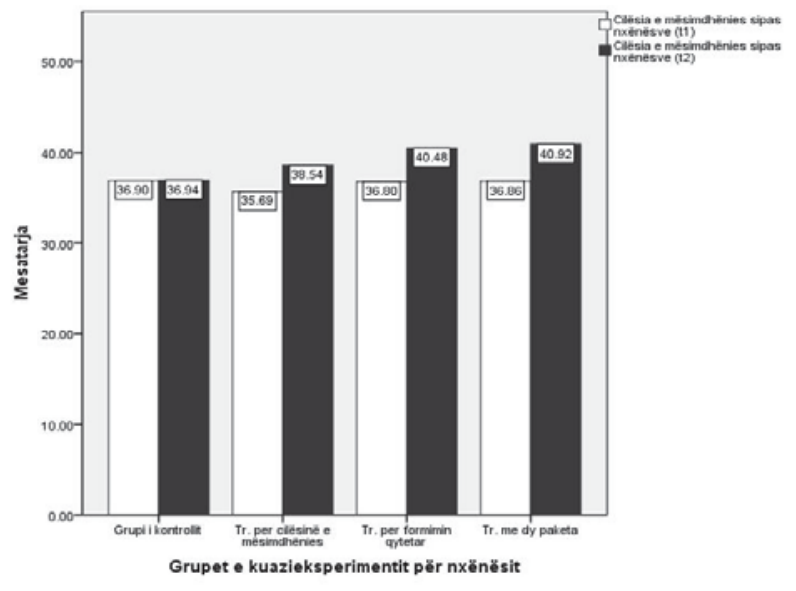

These results show that the teachers' training has influenced the teaching quality and that this impact has been reported not only by the teachers but even by the students. The results of this study confirm that the training with two packets has a stronger influence on the civic background as well as on the teaching quality. Both, the civic background and the teaching quality, are essential constructions which are related to active civility.

\section{Conclusions}

The findings of this study confirm that the teachers' training with two packets for the civic background and the teaching quality enhance their civic background, improves the teaching quality as well as their civic participation. Actually the teachers have their own background, they have a certain education level and several experiences which help them to perceive the elements and things in general faster. As they participated directly in the trainings, the reflection and the impact were immediate. The situation regarding the students' reporting is different; teachers' training for the civic background and the teaching quality increases the perception of the teaching quality but does not enhance students' civic participation. This situation occurs because the effects are not immediate and the students' awareness is slow. Furthermore, the students cannot reflect immediately due to the short period of time. However, even though the students gave higher assessments in the after-course phase compared to the pre-course one, no change was noticed in the level of their participation. A possible interpretation is the fact that the students feel more assertive in their own beliefs rather than their skills to act. Active civility cannot be the same in different groups of students. Furthermore, it is impossible to pretend that all the students profit at the same level in the subject of civics. This does not depend only on each student's skills, but even on their interest to become active citizens or not. Based on the major part of the research, which has been carried out so far, the impact on the participants is more important than the impact on the final beneficiaries (Patel 2003), or on the common community they belong to (McBride et al., 2006).

During the study it was noticed that among the sample of the teachers involved in the study, the males $(A=28.6)$ report a higher civic participation than the females $(A=28.1)$. This is mostly connected with the Albanian culture and mentality regarding gender differences, as there is a male dominance compared to women, who, despite the changes in our country, have not become active enough yet. In our society, the mentality that males have more time to practice different activities than women prevails. It is believed that women are engaged with the family life and have got very little time to dedicate to participation. The differences between the males and the females are created even due to the fact that mean are more engaged in politics, in different debates, which create the opportunities for participation.

Based on the work experience, a higher participation is noticed among the teachers who have been working for more than 20 years $(A=28.9)$. The teachers with an up-to-five year experience are less participating $(A=27.6)$. The youngsters are more indifferent and do not like to get involved. The right environment to organize activities has not been created yet, because the people are not aware of their roles and responsibilities they should have in the community. 
Often people's thoughts and opinions become an obstacle for the participation.

As far as students are concerned, civic participation is reported to be higher among women $(A=26)$ than among men $(A=24.6)$, so women are more participating than men. This happens due to the maturity that characterises women. They are more responsible and conscientious in the activities they undertake, they are better initiators and are more collaborative. As they live in democracy, they are more easy-going regarding social life and do not have complexes, establishing proportional reports between knowledge and the participation in the civic activities.

\section{References}

Birzea, C., Cekini, M., Harrison, K., Krek, J., Verkash,V., (2005) Instrument për sigurimin e cilësisë së edukimit për qytetari demokratike në shkollë.(Instruments for the provision of education quality for democratic civility at school)

Conclusioni del Consiglio del 12 maggio 2009 su un quadro strategico per la cooperazione europea nel settore dellistruzione e della formazione ('ET 2020'), OJ C 119, 28.5.2009.

Durr, K. (2004) The School: A Democratic learning Community. The All European Study on Pupil Participation in School. Strasbourg: Council of Europe.

Gora, C., Gore, V., Skolstvo, Z., (2007), Strategy for Civic Education in Primary and Secondary School in Montenegro 2007-2010, Unicef and the NGO Centre for Civic Education, fq. 32 .

Guomundur Heioar Frimannsson (2000), Civic Education in Europe: Some General Principles, fq.16.

Guomundur Heioar Frimannsson, Rheinische Friedrich Wilhelms (2000), Civic Education in Europe: Same General Principles.

Gjokutaj, M. , Shahini, L. , Markja, A. , Zisi, A. , Muça, E. ,(2005), Mësimdhënia me në qendër nxënësin, QTKA, Tiranë. (Teaching focusing on the student), http://www.research-advisors.com/tools/SampleSize.htm

Kaltsounis, T.,(1998), "Forces enhancing and inhibiting democratic citizenship education around the world ;the case of Albania", presentation at the annual meeting of the National Council for the Social Studies on November 20, Anaheim, CA, USA.

Karameta,P.,(2014), Arsimi i Gjeneratës Tjetër, Sara, Tiranë, fq.149. (Education of the Other Generation)

Ligji Nr.69/2012, Për Sistemin Arsimor Parauniversitar në Republikën e Shqipërisë, neni 58, fq. 19. (Law No. 69/2012, On the Secondary Education System in the Republic of Albania, article 58, pg.19)

Ligji për Sistemin Arsimor Parauniversitar, Tiranë 1995, fq. 7.(Law on the Secondary Education System, Tirana 1995, pg.7)

Qëndra e Trajnimit dhe Kualifikimit për Arsimin (2006), Programet e Trajnimit, Tiranë, fq.6. (Training and Qualification Centre for Education (2006), Training Programmes, Tirana, pg.6)

Rekomandime CM/Rec, të Komitetit të Ministrave për shtetet anëtarë për Kartën e Edukimit për Qytetari Demokratike dhe të Edukimit për të Drejtat e Njeriut të Këshillit të Evropës (Miratuar nga Komiteti i Ministrave në 11 maj 2010, në Sesionin 120-të të tij), 2010, Fq.7. (CM/Rec. Recommendations, of the Committee of the Ministers for the member countries for the Education Charter for Democratic Citizenship and of Education for Human Rights of the Council of Europe (Approved by the Committee of the Ministers on May 11 2010, in its 120th session), 2010, pg.7)

Strategjia Kombëtare e Arsimit, 2004 - 2015, fq. 14 . (National Strategy of Education, 2004-2005, pg. 14)

Vassiliou, A., L'educazione alla cittadinanza in Europa, fq. 3, Eurydice raport, (Vepër e cituar), Raccomandazione del Parlamento europeo e del Consiglio del 18 dicembre 2006 relativa a competenze chiave per l'apprendimento permanente (2006/962/EC), OJ L 394, 30.12.2006.

Vassiliou, A., L'educazione alla cittadinanza in Europa , fq. 3, Eurydice raport, (Vepër e cituar), Conclusioni del Consiglio del 12 maggio 2009 su un quadro strategico per la cooperazione europea nel settore dell'istruzione e della formazione ('ET 2020'), OJ C 119, 28.5.2009.

Weerd, M., Gemmeke,M., Rigter,J., Rij,C., (2005), Indicators for monitoring active citizenship and citizenship education, fq.64. 